maturing of the will among the Sikh community to exist as a separate nation against all odds -- a tendency that was manifested in the emergence of Sikh state within the Indian Union in 1966 and the current Sikh demand for a separate home land -- the Khalistan.12

The Suddhi and Sangathan movements of the $1920 \mathrm{~s}$ among the Hindus made the Punjab the home of Hindu consolidation and the provincial leaders of the Punjab hecame the chief spokesman for the Hindu cause of the entire subcontinent. The aim of both these movements was to put an end to the dally drain from the Hindus, who were being converted into alien religions in.thousands. The most urgent task for the Hindu Suddhi leaders to bring back to their fold, by reconverting them. The reconversion of the Muslim Malkan Rajputs in thousands or even lakhs 13 compelled the Muslims to fortify themselves by the Tab11gh and the Tazim movements. In spite of all the rhetoric the four Hindu-Muslim movements were defensive movements. It Is difficult to fudge the success of all these movements; but the damage done by all these movements in taking the Hindus and the Muslims apart was beyond repair. Psychologically these efforts kept the two communities on the alert to the possible "Aryanization" and the "Islamization" of the subcontinent.

The spread of 1 iteracy, and mass media of communication made the urban areas centers of nationalism and political consclousness. But in rural areas the surge of national ism was rather weak. But even in urban areas political consciousness was confined to the English educated minority, which was a very microscopic segment of the Indian population. The peasants of South Asla, largely illiterate retained their traditional alleglance to the village Mukhia (Chief). Political consciousness and its mobilization process also varied in India from region to region. The areas that were directly administered by the British had a higher level of polftical consclousness and a faster rate of economic development than those areas governed by the "native rulers." The British response to the demands of the Indlan national leaders varled according to time, place and regions. Where the national feelings were weak responses were weak. But at one stage or the other the growth of Indian nationalism was marked by constitutional and administrative, social and religlous reforms intended to satisfy or to dilute the rising expectations of the people; and in particular lowering the ambition of the individual national or regional leaders. The abolition of the human sacrifices (Sati, Thugi, and infatastde) in the social and religious sphere and constitutional reforms of 1909, 1919, and 1935 formed a part of the package of Britlsh response to the demands and the aspiration of the Indians.

While referring to the westernization of Indla by the British Karl Marx (1818-1883) wrote in 1853 that England "has broken down the entire framework of the Indian society, without any symptom of reconstitution reappearing." 14 It has "a double mission to fulfill ..... one destructive and the other regenerative the anahilation of the old Asiatic Society of despotism and the laying material foundations of the Western society in Asia:" "The destructive forces have been set in motion by imparting political unity, strengthened and perpetuated by electric telegraph; by introducing the first free press in Asla, a new and power- 
The process of westernization also led to the emergence of new classes and elites who spearheaded the social and rellglous revitalized movements.6 Along with them, each community. In India began to search for self-esteem and cultural Identity, which, however, was not an unmixed blessing. The search for cultural 1dentity, valuable as 1 t may have been in rousing hatred against colonial rule, did help to foster divisive trends in the Indian society. The major comnunities of India (Hindu, Muslims, and Sikhs) then began to draw thelr own heroes, prize their own myths and traditions and see in their own culture ingredents of nationhood. To make matters worse the heroes of one community became the villians of another; and the golden age of one became the darkest period of another. Thus, in the course of time two nation theory developed, which inflicted such a severe wound in the subcontinent that was never healed. As the wave of westernization engulfed the Indo-subcontinent the Muslims were not only the community to develop the concept of nationhood. In the nineteenth and twentieth centuries the Sikhs of India also felt that they were not Hindus; but a separate nation by themselves with a distinct language, script, religion, and culture - in short possessing a civilization of 1ts own.7 The Sikhs, however, did share some of the cultural traditions with the Hindus (both belleve in the sanctity of the cow, pipal and tulsi) so they did not go to the extent of carving out a separate state for themselves during the British rule in India. But they did manage to create a separate state for themselves in the Indian Union in 1966.8

The 1920s saw the Institutionalization of the concept of "nationhood" among the three major communities of India. The inauguration of the Gurdwara movement among the Sikhs, the Suddhi and Sangathan movements among the Hindus and their counterparts, the Tazim and Tabligh among the Muslims took the three communities further and further away from each other. Three factors provided an atmosphere conducive to these movements. The prominence recelved by religious leaders in national politics during the Non-Cooperation Khilafat days, the presence of strong communal organizations that were able to fill the vold created by the sudden suspension of the Non-Cooperation Movement and the implementation of the Montagu reforms which made the consolidation of numerical strength imperative among every country.9 Democracy became synonymous with majority rule. What appeared to be the flood of Hindu-Musl Im unity during the Non-Cooperation days proved only to be skin-deep, and the flood subsided only "to expose more noticeably the divergent reilglous prefudice." 10 The three major communities in the Punjab began to consolidate their. positions and in doing so emerged as the protectors of the Hindu, Muslim. and the Sikh interest in the entire subcontinent.

The Identity crisis among the Sikhs after the British takeover of the Punjab in the nineteenth century as reflected in the popular slogan like "Ham Hindu Nahin Hain" or in other words "we are not Hindus, "11 and the Singh Sabha movements, which matured into the Gurdwara movement of the 1920s. The aim of all these movements taken together was to strengthen the desire of the Sikh community to stand as one nation against the polftical domination by the Muslims and the cultural absorption by the Hindus. The greatest gain by the Sikh commity was the 
"bloody nonsense", and in the process completely allenated from their parent civilization. English education did in the beginning tend to change the taste and behaviour of the Indian students, thereby increasing the distance between the educated elites and the rest of the population - a distance that was already formidable due to the presence of the stratified caste hierarchy. The new English curriculum left many graduates illsuited to enter into the wider Indian society. Instead, the English educated elites of the Indian society formed a new caste or class of its own looking down upon their fellow-citizens. Many regarded English literature and language, English political institutions, and English concepts of beauty as their ideals and norms. Implicitiy, and explicitly they slighted their Indian culture. Some of them even viewed their own society and heritage with ambivalence or worse. 3 This group of Indians, though were quite large in number, yet, produced no leader of national or provincial repute.

A second group rejected completely the wave of westernization or the secularization process. The father of this movement was the mystic ascetic Swami Ram Krishna Paramhamsa, whose chief spokesman was Narendra Nath Datta (1863-1902), better known as Swami Vivekananda. He refused to be blown by the new wind that was coming from the West. He sincerely believed in the traditional wisdom of India, which in his opinion, was perfectly capable of gulding the destiny of modern India.4 A third group made a compromise between Eastern and Western values; and in this harmony and synthesis they visualize the solid base for future India. This was the most influencial section of the Indian elites and among them included towering personalities like Raja Ram Mohan Roy (1772-1833), Swami Dayananda Saraswati (1824-1883), Mahatma Gandhi (1869-1948), Moti Lal Nehru (1861-1931) and his son Jawaharlal Nehru (1889-1964). They took whatever was good in the Western tradition and modified it into the Indian system.5

It must, however, be pointed out that Kaja Ram Mohan Roy and the Brahama Samaj, Swami Dayananda Saraswati and the Arya Samaj, Swami Vivekananda and the Ram Krishna Mission had one thing in common. They all attacked caste system, contemporary religious practises and appealed their fellow brethren to the nobler traditions of the Indian culture. Some of them 1ike Swami Dayananda and Bal Gangadhar Tilak (1856-1920), even went to the extent of saying that the traditional forces were not contradictory to the secular forces. In fact, they were mutually compatible and could supplement each others growth and development. Both of them asked the Indians not to be awed by the might of British power, for, India had a long history of fighting, egainst foreign aggressors and a day would come when India would be emancipated from colonial rule.

Paradoxically, the process of Westernization also brought a revolt against India's past. The Hindu, Sikh and Muslim reformers of the subcontinent increasingly felt that their social and religious institutions had ceased to be dynamic. Thus, in an effort to preserve the good and beautiful of the historical past they made an attempt to remove the vell of fog and distortions that had enveloped thetr social and religious systems. In short, they looked upon the past as in a mirror and began to extract the useful traditions and phenomena they could use and leave the obscure, corrupt, and rotten ideas and practises behind. 


\section{Impact of Westernization in the Historical Development of India}

Prem Raman Uprety

The term westernization and modernization is often used synonymously in our times for to be modernize has virtually come to mean the act of walking on the path of development that is being pursued by the West. It is the liberating spirit of democracy that constitutes one of the movrecent recent years it has fathered the technological revolution that is rapid1y transforming the world. 1 However in the ancient had medieval periods India, China and the Middle East were the centers of modernity; and for a country to be modernized was to acquire "the moving spirit of the East." But by the year $1600 \mathrm{~A} . \mathrm{D}$. the seesaw began to tilt in favour of the West. In the West the seventeenth century was an age of genfus. 2 The modern world was born in the minds of intellectual luminaries like Galilei (1564-1642), William Harvey (1578-1657), Isaac Newton (1642-1727), Johann Kepler (1571-1630), and Rene Descartes (1596-1650).

Today, westernization or modernization, whichever expresston one would like to use, has become a world phenomenon. The twin forces of westernization and modernization created a revolution in British Ind la. This, however, does not mean that the forces of westernization created a revolution against itself; yet, the movement released such powerful and dynamic economic and political concepts that it served as a catalyst to a series of revolutionary process - a process that brought a renaissance among the diverse segments of Indian population. It turned the wheel of social and religious reforms, and revitalized movements, which culminated into a revolt against the Raj. The surge of Indian nationalism, which ended in the revolt against the colonial government was the most important symptom of the effects of westernization.

The colonial situation was very conducive to the growth of modern1zation process in India; and its impact was seen in the diverse segments of the Indian soclety itself. The Indians reacted three different ways to the new sets of changes brought about by the modernization process. One group accepted the forces of westernization in totality. In fact, we see in them a complete metamorphosis as exhibited in their changed life style, food habits, and their social and religious outlook. As the western values went into their veins they even changed their names and became Christians. Some in their euphorla of being emancipated from the "bondage of Hindu culture", labeled their traditional culture as

Dr. Uprety is Professor of History. Tribhuvan University, Kirtipur,
Kathmandu, Nepal. 
ful agent of reconstruction."15 He further observes thet the railroads, along with the multiplication of roads would destroy the village isolation and its accompanying "self-intertia". Again modern Industry "will dissolve the heriditary division of labour upon which rest the Indian caste system, those decisive impediments to Indian progress.16

But the Indian soctal and religious system had attained such a degree of maturity and sophistication that it refused to be blown by the wind of westernization as Marx had predicted. Political man in India even today is made of traditional materials. Acting through caste assoclations and federations he is capable at varfous levels to pursue power and authority and calculate his political advantage. The parties help to strengthen the group alliances and assoclations. "The result has been to make representative democracy meaningful and effective in a peasant nation and caste socfety."17 The study of caste politics in India shows a traditional powerful institution like caste has modified itself according to the needs of a democratic, secular society. The news head line from Statesman of June 19, 1961, namely, "Caste Hierarchy Declines As Castelsm Rises", sums up the case of modernity of tradition under the impact of secular forces.

When a traditional soclety like that of India goes through the forces of westernization or modernization or secularization, whatever expression one would like to use, three things can happen:

i. the system of government may adjust according to the social order and refect the forces of secularization;

11. the social orders may change Itself according to the wishes of the government; and

111. both the society and the government may compromise their Ideals and will reach a tolerable degree of consistency.

In her march towards modernization or secularization India in future will evolve a compromise between traditional and secular principles. The forces of secularization are too powerful for the Indian society to ignore completely, yet, the tradition is so deeply rooted in the Indian soclety that it is not possible to blow it out by a powerful wind from the West. It is neither possible for the Indian society to destroy the thousand years of tradition through a stroke of legislation nor is it possible for her to remain aloof from the secular culture on which man's civilization today is based. Ind ia today is experimenting a secular western culture in a country where the Hindus are the majority. So some may even conclude Indla will one day abandon the concept of secularism. But if we take into consideration the sizeable minorities 1ike the Muslims, Sikhs, Christians, Buddhists and Parsis, as well as the diversity and complexity in the Hindu society itself it is difficult anticipate the abandonment by India the concept of secularism in future. It is most 1ikely that India will evolve a compromise between secularism and traditional Hinduism and thereby evolve its own type of secularism or modernism. 


\section{Bootnotes}

1. More on the concept of modernity see Samuel H. Beer, Yodern Pol1tical Development (New York: Random House, 1974), pp. 94-125.

2. A. Whitehead, Sclence and Nodern Horld (New York: Mentor Books, 1980).

3. John McLane, The Political Awakening of India (Englewood Cliffs, 1970), pp. 5-85.

4. V1vekananda, Ingpired Talks, Yagter and Other Writings (New York: Ram Krishne-Vivekananda Center of New York, 1939): Yogeshwarananda, The Life of Swami Vivekananda (Almora: Advalt Ashram, 1949).

5. D. Mackenzie Brown, The White Umbrella: The Indian Political Thought from Many to Gandhi (Berkeley: University of California Press, 1968).

6. Perhaps, the best account of revitalized movements, in particular the Arya Samaj is found In Williams $\mathrm{K}$. Jones, "The Arya Samaf in the Punfab: A Study in Social Reformation and Religfous Revivalism, 1877-1902", unpubilished Ph.D. dissertation, University of Californ1a, 1966.

7. Prem R. Uprety; Religion and Politics in the Punjab in the 19208 (New Delh1: SterIing Publishers, 1980), pp. 63-72.

8. More on Sikh National1sm see Teja Singh, Sikhism: Its Ideals and Institutions (Bombay: Or lent Longmans, 1962), Pp. 56-74; Gokul Chand Narang, Transformation of Stkh1sm (New Delh1: New Book Society of India, 1960), Pp. 28-33.

9. IbId., p. 63 .

10. Correspondence between American Counc11, Karach1 and U.S. Department of State (International Affairs of Burma and India), August 8, 1923.

11. A Booklet in Punjab1 by Kahan Singh; background see Norman G, Barrler, The Stkhs and Thelr Literature (Delh1: Manohar Bbok Service, 1970), Pp. XVI' I-XV.

12. See L.S. Rathore, "The Problem of Khallstan", In B.A. Haqq1 (ed.), Democracy, Plurailism and Nation Bullding (New Delhi: N.B.O. Pubilcations, 1984), pp. 280-94; R. Kaur, Gopal Singh "Politics of Sikh Home Land", Ibid., pp. 295-324.

13. S.R. Sharma, Mahatma Hamsa Ra1: The Maker of Modern Punjab (Lahore: Arya Pradeshik Pratinidhi Sabha, 1941), p. 120; R.S. T1war1, Swami Shraddhnanda (Ajamer: Dianond Jubilee Press, 1927), p. 10.

14. Karl Marx, Selected Works, Vol. VI, "The British Rule in Ind1a" (Moscow: Progress Publishers, 1975), p. 652. 
15. Ib1d., 658.

16. Ibid., 658-660.

17. Lloyad I. Rudalf, "The Modernity of Tradition: Democratic Incaraation of Caste In India", Political Sclence Review, 1965, p. 985. 